\title{
CHILD POVERTY AND PERSISTENT LOW INGOME IN NORWAY - WITH SPECIAL ATTENTION ON THE SÁMI INDIGENOUS MINORITY
}

\section{ARNT OVE EIKELAND}

\section{ABSTRACT}

Economic inequality is increasing in Norway and creates outsiderness, including in the form child poverty. Child poverty is a term used about children living in persistently low income families. These are children in households in which total household income is less than 60 percent of the average income for at least three consecutive years. What characterizes a low income family? Low education, few resources, small personal network, poor health and a difficult social background. I.e. those who lack a buffer for unforeseen expenses. Children with an immigrant background are overrepresented in this group, accounting for 54.5 percent of all children in Norwegian poverty statistics, i.e. 92,000 children. The Sámi indigenous minority is also exposed. A total of 123 children or 22.2 percent of the children in, for example, Kautokeino municipality live in poverty. To uncover more aspects of this issue, I have chosen both a theoretical approach and an approach that is based on data from a Sámi core area, Kautokeino. In the theoretical approach, emphasis is placed on how the interpretation of relative poverty and child poverty can be understood in a rich egalitarian democracy such as Norway. The increasing economic inequality in Norway leads to child poverty, and growing up poor in a rich country has major psychosocial consequences. 
In the empirical section, I choose Kautokeino as an example for discussing this question. Kautokeino acts as an indicator, because it clearly shows the full extent of the problem. I, to answer the question, look for connections between low income, lack of education and the effects of colonization.

\section{INTRODUCTION}

Economic inequality is increasing in Norway, this creating outsiderness including child poverty. Many explain this phenomena using neoliberal politics and economics. In a global context, however, the Nordic countries have the least economic and social inequality. This is linked to the Nordic welfare model. The model's characteristics are universal welfare schemes, emphasis on an active labour market policy, gender equality and redistribution through tax-financed welfare. Who, however, ends up in the lower economic strata of an otherwise egalitarian Norway? The research foundation Fafo's report (2009, p.45) on Child Poverty in Norway points to three groups that are particularly vulnerable to poverty. They are single parents, ethnic minorities and the unemployed.

I live in a small Sámi community in Finnmark and hear about children in the Sámi core areas that are exposed to child poverty. The statistics for 2017 confirm what I hear (Bufdir, 2017). As many as 123 children or 22.2 percent of children in Kautokeino live in persistently low income families. Other municipalities in Sápmi also have a negative impact on the statistics. In Karasjok 54 children (12.3 percent) and in Nesseby 21 children (16.1 percent) are affected by child poverty (SSB.no/kommunefakta). An average of 10.3 percent of children in Norway live below the defined poverty line.

The problem I will discuss in this chapter is therefore: How can the high levels of poverty for the Sámi core area recorded in the statistics be explained?

I have chosen two approaches to uncover more about this issue. One theoretical and the other based on data from a Sámi core area (Kautokeino). In the theoretical approach, emphasis is placed on how relative poverty and child poverty can be understood in a rich egalitarian democracy such as Norway.

In the empirical section, I choose Kautokeino as an example to discuss this question. Kautokeino acts as an indicator, because it clearly illustrates the total problem. I will, to answer the question, look for connections between low income, lack of education and the effects of colonization.

There is some research on issues such as school dropout rates that suggests that these statistics can be an indicator of outsiderism (Nystad, 2003; Valmyr, 
2017). Only a few social scientists and the Norwegian authorities have, however, addressed the problem of child poverty. The main aim of this chapter is to raise this issue and document the problems of child poverty in indigenous minorities and its contribution to specific measures in a decolonialization process. I, as a philosopher, will use theories from different academic fields to discuss the phenomenon. A multidisciplinary approach will bring out a number of aspects of the phenomenon of poverty.

\section{RELATIVE POVERTY}

767 million people today live in so-called extreme poverty with an income at or below $\$ 1.90$ per person per day. These people cannot today, in practice, meet their own needs (SDG Progress Report, 2017). This is absolute poverty. The choices available to those experiencing absolute poverty are narrowed to providing life necessities. The individual is therefore not given the opportunity to enjoy the freedom to realise her/his wishes and abilities, those in absolute poverty only have the opportunity develop her/his human potential to a very small extent.

Life necessities are not the main theme of the relative poverty category. Economists have not been mainly concerned with the physical (e.g. thirst and hunger) of poverty, nor with the shame that is attached to it. In the book The Affluent Society, economist J.K. Galbraith (1998) implies that people will be immediately affected by poverty if their income, even if sufficient for survival, drops noticeably below the general income level. Those who cannot acquire what the larger community considers to be a minimum requirement for decency, are easily judged by that society to lack decency.

Sociologist Peter Townsend defines relative poverty as follows (Solstad, 2011, p.59):

'Individuals, families and groups in the population can be described as poor when they lack the resources to obtain that diet, participate in those activities, and have the living conditions and conveniences that are common or at least generally accepted in the communities they belong to. Their resources are so far below the average individual or average family that they are excluded from normal life patterns and tasks. It is therefore assumed that people compare their own situation with that of others, and that there are certain common norms in society for what are acceptable and unacceptable living conditions'. 
A relative understanding of poverty is thus based on social norms and reference groups in society. Sociologist Per Schieffloe (2019, p.310) emphasizes that reference groups are a form of yardstick in the social landscape. Our sense of what a yardstick, for example, for wealth and honour implies, does not arise by itself. The scale arises when we compare ourselves with a reference group, with those we consider our peers. Norwegians are extremely wealthy in a global context. They are, however, not impressed with wealth. We are more concerned about whether we have as much, or a little more, than those we grow up with, work alongside, are friends with, and identify ourselves with in the public sphere. Norwegians usually do not envy extremely rich people such as Bill Gates or Georg Soros. One of the seven deadly sins of Catholicism relates to envy. We only envy members of our own reference group, the success of our closest friends often being the most difficult to accept. Consequently, the more people we perceive to be our peers, then the more people there are that we can envy.

Townsend's definition relates to the individual's social situation. This is a philosophy that goes back to Friedrich Hegel's resolution of two earlier philosophical conceptions of the self: the Platonic and the Kantian. The idea of self-realisation also has its roots in this. Identity (who I am) becomes a theme. The philosopher Charles Taylor (1994) takes his stand in Hegel's understanding of personality formation. He sees a strong connection between identity, authenticity and recognition. He says that human life is fundamentally dialogic in character. We are 'woven' into each other through interaction; through language. I am dependent on the other for me to be who I am. Failure to be recognized can damage my identity. Being recognized can strengthen my identity.

The philosopher Lars Svendsen (2011) claims that we would, in a perfect world, know what we were worth. However, as we do not live in such a world, we are vulnerable because we have many and often contradictory perceptions about our character. The need to anchor our existential situation as bodily and social beings causes our sense of identity to be captured by how we are judged by the surroundings. We are fragile creatures who are concerned with and dependent on how others perceive us, and are therefore uncertain about our own value. We have an ability to think about what others think, believe and feel about us. Therefore, our self-confidence is difficult to maintain when others have stopped showing us respect. 


\section{CHILD POVERTY}

Child poverty is a term used about children living in persistently low income families. That is, children in households whose total household income is less than 60 percent of the median average income for at least three consecutive years. What characterises a low-income family? Characteristics of such a family are low levels of education, few resources, small personal network, poor health, difficult social background and the lack of a buffer for unforeseen expenses (Harsløf \& Seim, 2008). Only the cash income of the household is included in the income concept. The value of public services such as free or subsidized day care centres, health services and leisure activities are not included in this income. Neither is the value of home produced services such as unpaid care services provided by relatives, neighbours, or friends (SSB, 2019).

What are the psychosocial consequences and challenges of growing up in a low-income family in a rich country such as Norway? Poor children in Norway may be materially better off than poor children in other countries. It is difficult to imagine the idea that one can be respected and at the same time be poor in today's Norway. Being a poor child in Norway may therefore be mentally more difficult than in other countries. Philosopher Alain Botton (2005) emphasizes that owning a lot does not, first and foremost, bring joy. It does, however, instil respect. Even the anti-materialist will feel a pressure to accumulate property and display it, so as not to feel shame. Economist and Nobel laureate Amarta Sen is one of the world's foremost poverty researchers. Sens's hypothesis is that there is a link between poverty and shame all over the world. Feelings of shame are something poor people feel all over the world, even if they live in a western welfare state such as Norway. Researcher Ivar Lødemel agrees with Sen, saying 'Our findings show that this is true' (The Research Council of Norway, 2017). Economist and moral philosopher Adam Smith (1759), when writing that poor people are often looked down upon in the book Moral Sentiment, arrived at the same conclusion. Wealth and power are compared with and respected in the same way as wisdom and bravery.

Another key concept in this debate is social exclusion. Poverty is often linked to social exclusion in the European debate. The term describes a social position in which the lack of financial resources forms part of a situation of incomplete citizenship. Poor children cannot afford to participate in what 
others in the local community take part in. This can mean being excluded from leisure activities, birthdays and everything else that give children a safe environment, interesting lives and the feeling of being a community participant. Leisure activities are social arenas in which social skills are developed, networks are built, and children gain access to experiences that create mastery and meaning. It is a fundamental right that a child must be allowed to participate in the arenas in which social interaction takes place. The consequences of material loss and feelings of being a loser can lead to impaired self-esteem, lower inherent worth and negative self-image. This can affect the child's development and have consequences that extend throughout his or her life (Underlid, 2008). Children who grow up in low-income families can therefore be socially excluded if not allowed to participate in the activities other children participate in and lose access to the informal learning that takes place in organizations and other leisure activities. Children may be excluded from sports, not because they cannot afford to pay the training fee, but because the equipment is expensive. It also costs money to go on school or leisure trips. This exclusion can, in turn, lead to difficulties remaining integrated in the community. Financial inequality is also often interpreted as a violation of the principle of equal opportunity. Children who grow up in poor families have poorer living conditions and fewer chances of life than other children. Asgeir Solstad (2011), who is a professor in social work, believes that society must become better at arranging that all children participate in activities irrespective of family economy.

Psychologist Tone Fløtten (2009) claims that child poverty was a non-issue just a few years ago in Norwegian politics and research. It has, however, gone from being a non-topic to being one of the most debated social issues. Low income or income poverty is often used when discussing the extent of poverty. This is the starting point for both the EU's, the OECD's and UNICEF's definition and targets for poverty. The use of such goals does, however, not take into account people's other living conditions nor their subjective experience of whether they are poor or not. Poverty is a normative problem. No poverty targets are therefore intangible.

There is no clear or true answer to the question of when does child poverty occur. Low income is a relative term. The low income limit is determined in terms of the distance between this limit and the general level of income in society (median income). There has been a significant improvement in Nor- 
wegians' objective living conditions in recent decades. Growth in financial prosperity, such as income, wealth and access to material goods, has increased sharply. This has also benefited the most disadvantaged, the low income limit therefore also moving upwards due to the strong growth in the Norwegian economy. This means that the relatively poor have a much higher material standard in the absolute sense, even though they are still locked in a state of fewer financial resources than the average household. Norway also has Europe's lowest income inequality. There has, however, been a significant reduction in the proportion of people with low income in recent decades, if we base this on a more absolute definition of low income that uses the annual low income limit for 2000 adjusted for inflation. This means that the large real growth in income for households that has occurred in the past 15 years has also benefited those at the bottom of the income distribution. The income gap has, even so, increased (Fagarkivet, 2019).

Discussions in the field of 'poverty research' often revolve around pure income targets and how many consumer goods a person lacks. This is a narrow approach. 'Boiling' the complexity of the case down to materialism and money, and to the premise that human consumption is the 'highest value' of the West has, in many ways, also been accepted. Contemporary diagnosis is therefore quickly lost in questions such as: In what kind of society do we live?

Many would say that we live in a society that is moving in a neoliberalist direction. Simplifying this roughly, we can say that neoliberalism elevates the market as a governing arena, and recommends that economic thinking and methods be disseminated in more and more areas of society, including within state and municipal enterprises. The present Norwegian state formation is called markedsstaten, 'the market state', as opposed to the former embetsmannsstaten, 'the state of public officials', as referred to by the historian and political scientist Rune Slagstad (2019). This also applies to complex services such as education, child welfare, elderly care and health services that should now be profit-driven. It is assumed that the market is largely fair and democratic and will create economic efficiency that benefits everyone. This not least applies to children who are pressed into arenas that are becoming increasingly commercialized, access to most arenas costing money and revolving around money. One example is leisure activities. What are the consequences of this development upon children? The sociologist Frønes (2011) believes that consumption in a consumer society is implicitly understood to be a source of identity 
formation for children in the material carousel. The commercial child is often associated with certain children's products that are often promoted in advertising. Market forces define what it takes to be happy. Philosopher Micheal Sandel (2012) emphasizes that the market is influential. If you pay someone to be a friend, then there no longer is a friendship. The philosopher Plato defined happiness as being something that is achieved through knowledge and insight. Teaching a child to maintain a one-sided focus on materialism and an excessive and unhealthy consumption, hardly increases the feeling of happiness. Today's Norwegian children are, however, socialized into a lifestyle based on consumption. The philosopher Immanuel Kant would say that this is not universalisable. Children in today's society can hardly be blamed. How do these empirical changes based on market logic effect our everyday lives? How do they influence our minds, our emotions, our mental health and our view of other people? In the book The art of shrinking heads (2007), philosopher Dany-Robert Dufours states that neoliberal ideology puts our institutions at risk and begins to define 'what we are'. Political analyst and historian Thomas Frank (2001) says the same when stating that he believes that the market has become the very image of what society is, what being human is all about. The market has increasingly become the arena in which we will emerge, and show who we are.

In this section, I have argued that social problems and challenges arise in the relationship between the individual and society. The focus in this has been on children living in persistently low income families, and the social consequences of this. In the next section I will, however, address societal, cultural and economic causes of the problem of child poverty in Kautokeino.

\section{KAUTOKEINO}

Kautokeino municipality is bordered by the municipalities of Kvænangen, Alta and Karasjok. It is, by far, Norway's largest municipality. Around 90 per cent of the population has Northern Sámi as mother tongue, and the municipality has for a long time been the only municipality in the country to give Sámi language the same status as Norwegian in the public administration. Reindeer husbandry is an important Sámi culture carrier, around 1,700 people being employed in this field. Half of the municipalities 2,911 inhabitants live in the centre (SSB/ 
kommunefakta Kautokeino) and the municipality is Norway's largest reindeer husbandry municipality. There are a number of institutions in Kautokeino, such as: Sámi allaskuvla, Beivva's Sámi national theatre, the Sámi upper secondary school and the reindeer herding school, The International Center for Reindeer Husbandry, a department of the Sámi Parliament, the Sámi archive, Kautokeino film, the International Sámi Film Institute, the Sámi art and craft centre (Duodjeinstithutta), the Norwegian public broadcasting company's Sàmi radio and the Sámi language newspaper Avvir. The Norwegian Sámi National Federation and the World Reindeer Peoples Organization are also headquartered in Kautokeino. What could, therefore, help explain the high rates of child poverty in Kautokeino? Visions and challenges for Kautokeino are described in the social section of the municipal plan. The plan is for 2017 to 2030. We can read that Kautokeino is described as - 'the wizard of Sápmi' (Kautokeino. kommune. Kommuneplanens samfunnsdel, 2017). Emphasis is placed on Kautokeino as being the place in the world where the Sámi language, Sámi culture and Sámi industries are strongest and are the most viable. Kautokeino is therefore considered to be the cultural centre of the Northern Sámi region. Challenges in finances and living conditions are described as follows:

Kautokeino has low average incomes. People remaining out of work and other important arenas over a period of time, increases the risk of social differences. This can result in huge costs to the individual and society. Children and adolescents, single people and families with children are of particular concern. Work is a source of income, financial security, self-respect and self-realization. The municipality of Kautokeino must work to create higher levels of employment, that contribute to securing the welfare community, the levelling of financial and social disparities and the prevention of poverty (Kautokeino Kommune. Kommuneplanens samfunnsdel, 2017, p.11).

Large differences in levels of education and income indicate that there are large social and health differences in the population. These figures also raise concerns in the social part of the municipal plan. It is emphasized that women in Kautokeino have the highest levels of education and salaries. This therefore means there are reasons to pay special attention to men's health and welfare. The number of people under 45 with disabilities is higher in Kautokeino than 
in the rest of the country. Unemployment is also higher than the rest of the country, unemployment among men however declining. Many of the unemployed have little or no education, making it difficult to compete in the labour market place (Kautokeino kommune. Kommuneplanenes samfunnsdel, p.17).

2018 figures show that Kautokeino is the municipality in Finnmark with the lowest average income, which is NOK 230,760 (23535,65 EUR). The average income in Finnmark is NOK 286,217 (29191,82 EUR) and the national average is NOK 310,207 (31638,60 EUR). At the same time, the 100 highest earners in Kautokeino earn well above double the national average. These are mainly those with higher education and who work within different industries in the private business sector (Skatteetaten.no). Kautokeino and Karasjok are the only two municipalities in Norway where women have a higher gross income than men (DN 9/9 2019).

The problem of child poverty has been covered in the Finnmark media in the past year. Kautokeino has, in particular, been widely discussed. I therefore relate to the understanding of the problem that emerges in the press's comprehensive coverage of high child poverty rates. This provides an important insight into a locally felt problem area that is only problematised to a minor extent by authorities and social scientists. The problem came to the surface in the newspaper Altaposten (27 June 2018) through an interview with the Norwegian Labour and Welfare Administration (NAV) leader in Kautokeino. She is unsure whether a middle-aged unemployed user will be able to create a new life under global capitalism. She says:

There are still deep traces in society after the Norwegianization of the Sámi, and we know that the Sámi in general have not had the same higher education opportunities as the majority population in Norway. Getting an education and further education in Kautokeino 30 years ago meant you had to travel far from home, and then first learn the Norwegian language, as the education system was based on the Norwegian language and the teaching was in Norwegian. That is why many people ended up in low-wage jobs. Gaining a certificate of completed apprenticeship and educating yourself as a 50-year old is not easy. Now we have to build a whole new generation and make them successful. 
Further, in Altaposten (Altaposten, 06 June 2018) we can read:

In Kautokeino, there are 932 people over the age of 16 who only have basic compulsory school and we see a mismatch between those who are unemployed and what is required by advertised positions. "People simply do not have the skills required to get these jobs," says councillor Kent Valio, who runs a municipality with many state institutions, and where academic education is required.

Kautokeino municipality's Action Plan on Child Poverty concludes that education and work are the main solutions to the problem of poverty in Kautokeino (Kautokeino Kommune, 2017).

\section{INDIGENOUS PEOPLES AND MODERN SOCIETY}

There are between 220-350 million people belonging to the indigenous peoples of the world. Movements emerged in the 1970s that promoted the rights of indigenous peoples, and there is a great deal of explanatory power in the rights' struggle globally in the 1970s in understanding the rise of the Sami Parliament. Much of that struggle had its roots in the miserable living conditions under which indigenous peoples lived. The political scientist Engkvist (2006) claims that indigenous peoples rank poorly on most living conditions surveys and health statistics. The Sámi have participated in and experienced rapid development since the Alta case and the rights struggles in the 70s. This includes establishing the Sámi Parliament, the new language law on the right to Sámi language, Sámi census and other institutional establishments. The purpose has been, and still is, to build a platform that ensures that the Sámi indigenous minority has the instruments to become more equal with the majority population. Today, institutions have been developed to help create political freedom and freedom of action on Sámi premises (Aarseth, 2006). This struggle for rights has mainly been led by educated Sámi. These people are today the highest salaried in modern Sámi society, and many people say they have a defining power over the content of the Sámi 'project'. Research should therefore be conducted into whether class distinctions in the Sámi community are emerging, based on those who are educated and those who have not clearly had any form of education. 
The development of the modern state has progressed very quickly for Arctic indigenous peoples. They have essentially moved from being a people who had adapted their way of life to industries which could be operated in the Arctic, to a more modern way of living. The traditional industries have been consistently difficult to adapt to modern times and efficiency demands. Industries that used to be adapted to fragile nature are now industries that must meet the requirements of market liberalism, i.e. exclusively economic 'sustainability'. It has not been possible for ignorant state authorities nor for Sámi fishing or reindeer herding to meet these challenges. Many Arctic indigenous peoples can, therefore, be caught in the gulf between tradition and forced, not adapted, modernity. State authorities and regulations are characterized by a lack of knowledge about primary industries in the Arctic (Henriksen \&Hydle, 2016; Riseth, 2016; Löf, 2016). A physically demanding nature and poverty and racism have, over the centuries, taught the people in these areas to survive under harsh conditions, both in nature and in society. The geographical and climatic location means that the Sámi have adapted to a challenging terrain and climate and have had, and still have, a practical way of thinking. The old traditions and knowledge are still emphasized in people's myriad tasks and language expressions. They still contain knowledge on traditional industries and how to cope in one of Europe's coldest areas. Much of this knowledge is not written down or articulated in a scientific way, but lives in the bodies, in the language, and through metaphors and narratives (Ween, 2017). A natural consequence of practical knowledge being so highly prioritized in Sámi areas, is that many do not travel beyond the place where they were born and raised. Boys in particular tend to prioritize this way of life (Boine, 2010). This effect can be compounded by the fact that many adults also do not see the importance of formal education. The social class of parents determines the level of cultural, social and intellectual resources they transfer to their children (Bufdir. 2017). These considerations may be part of the reason why boys drop out of school or do not start high school after basic compulsory education. Studies are being conducted into whether those who leave basic compulsory education in Sámi areas have such a weak academic foundation that they would not be able to complete secondary school. There are also a very high number of boys who drop out of high school (Valmyra, 2017). The girls are doing better. Nystad (2003) claims that identity is particularly well grounded locally in Kautokeino. Leaving 'the known' and travelling to another place for education can therefore be a major barrier. Many also fear racism 'out there'. Nystad empha- 
sizes that practical knowledge is involved in 'defining' Kautokeino. In the Sami newspaper Sagat, the Kautokeino councillor is interviewed:

Kautokeino still has a relatively high degree of self-support culture, which is evident in the utilization of fishing, outfield, and berry picking. In the application for restructuring status, we can see that it has made people in Kautokeino do well with low pay, without this having a negative effect on a family's living. But today, money is more important than before. So many end up in a clinch they can't escape. Many also have no education beyond elementary school, as formal education is not required to utilize natural resources. There is a big gap between jobseekers' skills and the skills required to get a job in Inner-Finnmark. Far fewer than are usually registered have completed high school. One of our biggest problems are youth, especially young men, who are unable to complete a higher education pathway and therefore gain the necessary competence in an increasingly demanding labour market (Sagat, 6 February 2018).

The self-support culture is, as the mayor knows, highly alive in Kautokeino. Fish, game, berries and other outdoor resources put food on the table. These activities are also an existential dimension of societies such as Kautokeino and a legacy from former times, when man and nature united in a higher unity. These places therefore constitute a corrective to modern capitalist societies. This means that individuals and families have managed on a low wage income, without this necessarily having a negative effect on the family's living and quality of life. An increasingly neoliberal society in which commodities are the yardstick of money, means that such a way of living is becoming increasingly harder. Modern commercial society does not seem to open up alternative ways of living that are not based on money (Ehrenreich, 2006). Fløtten (2009) also argues that a discussion of people's perception of what is considered acceptable material living conditions is needed. Living conditions are more than just income. Living conditions include physical and mental health, living conditions, living environment and immediate surroundings, social contact, relationships with leisure activities, conditions related to crime and violence and to pollution, noise and traffic. Today's challenges of climate crisis and sustainability are likely to drastically change the climate of consumption and living conditions in the years to come (Hydle \& Henriksen, 2016). 


\section{SOCIAL HERITAGE AND EDUCATION}

Are we approaching meritocracy in Norway? Fløtten (2009) emphasizes that family background is of great importance to children's development. Children of parents with low levels of education or low income have poorer opportunities for success in education and working life. This is how poverty is 'inherited' (Fafo-rapport, 2009, p.50). What social and cultural disadvantages are passed on from generation to generation? Factors such as humanism, culture and traditions may contribute to this inter-generational transfer, the reproduction of social inequality perhaps being the most important of these. There are at the same time, of course, opportunities for social mobility in different contexts. School dropout and a lack of understanding of the value of education are not 'hereditary' as genetic predispositions. I therefore choose, in the search for mechanisms or individual characteristics that can contribute to understanding this, to provide a thick description (Geertz, 1973) of why it is difficult for many indigenous peoples to adapt to a society which the Polish sociologist Zygmunt Bauman (1989) describes as ordered throughout. According to Bauman, the main theme of modernity is the process of the thorough rationalization of society. This process has created a bureaucratic iron cage in which we are imprisoned by the maxim of industrial capitalism's efficiency. Adorno \& Horkheimer (2011) have predicted the narrow worldview that lay ahead of this process in their cultural critique of market excellence and the one-dimensional economic worldview. This worldview conveys a way of thinking that measures a country's success in market economic growth rates. Life is measured by market economic frameworks and terms. Existence is quantified in numbers and indices.

The crafts and skills that have been the cornerstones of Sámi society are becoming 'dead meat and cutaway' in the capitalist machinery. This represents a loss of human resources and skills. This results, for those involved, in the giving up of a stable life and clinging to temporary jobs in the more unstable sectors of society. The psychosocial effects of this for those involved, can quickly become lower self-esteem and poor income. A number of indicators show that aspiring egalitarian Norway is developing a sorting society in which human dignity is graded according to the ability to meet the narrow and demanding requirements of the competitive market economy. Those who do not want to or cannot discipline themselves into this economic 'performance society' are, 
for example, labelled ineligible, school dropouts, disabled, unemployed, poorly integrated, social clients, new-poor, debt victims, weak groups and lower social classes (Shammas, 2019).

Education is the single factor that can easily be converted into work. Low levels or no education can therefore be understood to be a contributing cause of persistent low income. Today's working life places ever higher demands on competence, which makes many in the labour market vulnerable. The road to qualifying for the Norwegian labour market can soon be long. The premises for future working life will therefore be documented expertise through higher education courses. There will be fewer jobs for unskilled workers due to factors such as digitalisation, including in manual professions. Those who do not manage to complete a theoretical education pathway will therefore experience great difficulty in the labour market. Many young people find adapting to a school that is based on theoretical knowledge, difficult. The school is an expression of the kind of society we want in the future. The mentality we find in many indigenous communities breaches with these rules of the game, and falls outside what is called the normal framework of society. This is well stated by Nystad (2003, p.133):

Giddens believes that in modernity, one does not cope with the local knowledge that one acquires through relatives and family. The way I interpret the informants, is that it is not possible to manage in Kautokeino without local knowledge. Local knowledge is important, and it is not sufficiently integrated in schools. So students must therefore be absent from school or opt-out of education, to learn the local knowledge. The hypothesis that seems to be most valid is: Education is important, but there are other things that are also important.

\section{DECOLONIZATION}

Another approach may be to look at the repercussions of assimilation. The official policy from 1850 was that the Sámi should be assimilated into Norwegian society. Today, the official attitude is that the state of Norway is founded on the territory of two people (Aarseth, 2006). After a hard and long assimilation process, the authorities are required by Article 108 of the Constitution to take measures to secure the Sámi language, culture and social life and facilitate 
development opportunities. This opens the question of whether assimilation and colonization are stages that have ended, or whether these processes continue in new forms and inhibits people from, for example, getting an education? There is little doubt that assimilation, colonization and racism have had negative consequences for the Sámi population. Many feel insecure and unsure in their ethnic, geographical, social and cultural affiliation. It is also important to distinguish between generations, because the Sámi have, after 1980, been through a revitalization process. The revitalization process has ended differently depending on the Norwegianization process. Some have tackled this well and have a safe identity. It has, however, for many led to emotional conflicts, frustrations and dilemmas. A lot of suffering is hidden in the gap between the Norwegian majority and the Sámi minority.

The psychiatrist Franz Fanon addresses the relationship between the oppressor and the oppressed in the book Jordens fordomte (2002) (Les Damnés de la Terre, 1961). It is still a core text in postcolonial studies and racism research. He addresses topics that are fundamental to understanding the social and psychological consequences of racism, colonialism and oppression. Fanon says man is first and foremost an active being. Fanon's understanding of Self is based on Hegel's philosophy. The Self is not monologically produced, but dialogic in its ontology. The Sámi subject is, in many ways, created through decades of oppression and racism. Being identified as Sámi in the majority's condemning language style, was to be categorized in the most diverse ways through stereotypical conceptions. No one is a 'born Sámi'. One is created through 'the other's gaze'. This construction, or self-construction, of a Sámi consciousness therefore exists in a submissive relationship with the majority population. This relationship can be broken by creating new concepts, which in turn can open the imagination for change. How this should occur calls for a broad debate. It should not be carried out by 'essentialist folklorist' researchers, but by researchers who see the Sámi of today as being different from the Sámi of the past. It is hard to defend the claim that there is an authentic culture that can be restored, as the culture has been changed by, for example, colonialism. Being Sámi is not a fate, as communicated by internationally acclaimed and award-winning artists such as Mary Boine, Sofia Jannok or Ella Marie Hætta Isaksen, who have had success and made careers. They represent a Sámi form of modernity. The Sámi are also the indigenous peoples of the world with the highest levels of higher education, especially women. The focus today should therefore be on those who have no voice in Sápmi, in particular men, who have not been able to create a space within Sámi modernity. 


\section{SUMMARY AND CONCLUSION}

Market fundamentalism is the dominant ideology of our time, says social scientist Sofus Tranøy (2014) in the book Markedets makt over sinnene. Tranøy points out that poverty differences decrease between nations, but that the economic differences become greater within nations. The increasing economic inequality in Norway leads to, among other things, child poverty. Growing up poor in a rich country also has major psychosocial consequences. These negative consequences are further exacerbated in a society that increasingly promotes unhealthy competition in arenas such as school and sports and in a society that promotes consumption as a source to identity.

Not all low-income families see themselves as poor in Sápmi and not everyone who is poor experiences their situation in the same way. All individuals and families are different, including low-income families, even though they are defined as a group. There is here a phenomenological perspective. The experience of those who are exposed to child poverty, i.e. how children perceive their situation, must be analysed. My theoretical and empirical documentation shows the necessity for exploring the social and social science measures that should be implemented to counter child poverty in Sámi core areas, and that this should be through a decolonialization process. This chapter can be seen as a first step. 


\section{LITERATURE}

Aarseth, B. (2006). Norsk samepolitikk 1945-1990. Drammen: Vett\&Viten.

Adorno, T.W., \& Horkheimer M. (2011). Opplysningens Dialektikk. Norsk utgave. Spartacus.

Altaposten 6. juni 2018 and 27. juni 2018.

Bauman, Z. (1989). Auscbwitz och det moderna sambället. Göteborg: Daidalos.

Boine, E. (2010). Kulturorientert praksis - en veileder. Barnevernets utviklingssenter i Nord-Norge.

Botton, A. (2005). Statusjag. Oslo: Damm \& Søn AS.

Bufdir. (2017). Statistikk og analyse. Barnefattigdom.

Bufdir. (2017). Opprekstrapporten. Artikkel 2 av Ivar Frønes. Barne,-ungdoms-og familiedirektoratet. retrieved from https://bufdir.no/Statistikk_og_analyse/ Barnefattigdom/\#/

Dagens Naringsliv 9. september 2019.

Dufour, D.R. (2007). The art of shrinking heads.Cambridge: Polity Press.

Ehrenreich, B. (2006). Lokket og lurt. Oslo: Oktober.

Engkvist, Y. (2006). Urfolksrettigheter i en canadisk kontekst. Tidsskrift for urfolks rettigheter $\mathrm{Nr} .3$.

Fafo rapport. (2009). Barnefattigdom i Norge. Fafo rapport 2009: 38, retrieved from https://www.fafo.no/index.php/en/publications/fafo-reports/item/ barnefattigdom-i-norge

Fafo rapport. (2009). Aktivitet og deltakelse for fattige barn og unge. Fafo rapport nr. 50, retrieved from https://www.fafo.no/index

Fagarkivet. (2019). Child poverty and children in low income families. Retrieved from http:hioa.archive.knowledgearc.net/bitstream/handle/20.500.12199/1304/ NOVA-Notat-2-2019-Child Poverty-and-children-i-lavinntekstfamilier.

Fanon, F. (2002). Jordens fordomte. Oslo: De norske Bokklubbene. (Wretched of the earth - original Les Damnés de la Terre, 1961)

Fløtten, T. (2009). Barnefattigdom, p.15-24, i Fløtten, T. (Eds.). Barnefattigdom i Norge. Oslo: Gyldendal akademisk.

Frank, T. (2001). [BOOK REVIEW] One market under God, extreme capitalism, market populism and the end of economic democracy. New Statesman, 130, $50-51$.

Frønes, I. (2011). Moderne barndom. Oslo: Cappelen Damn.

Galbraith, J. K. (1998). The Affuent Society. A Mariner Book. Hougton Mifflin Company. 
Geertz, C. (1973). The interpretation of cultures. (Vol. 5019). New York: Basic books. Harsløf, I., \& Seim, S. (2008). Fattigdommens dynamikk. Perspektiver på marginalisering $i$ det norske samfunn. Oslo: Universitetsforlaget.

Henriksen, J. E., \& Hydle, I. (2016). Participatory handling of conflicts in Sámi areas. International Social Work, 59(5), 627-639. https://doi.org/10.1177/0020872816650731

Kautokeino kommune (2017). Handlingsplan mot fattigdom 2018-2020, kommunestyre i Kautokeino 14.12.2017.

Kautokeino kommune. Kommuneplanens samfunnsdel 2017-2030, kommunestyre i Kautokeino 23.03.2017.

Löf, A. (2016). Locking in and locking out: a critical analysis of the governance of reindeer husbandry in Sweden. Critical Policy Studies, 10:4, 426-447. https://doi.org/10.1080/19460171.2015.1098552

Nystad, K. M. I. (2003). Mannen mellom myte og modernitet. Drammen: Vett og Viten.

Riseth, J. Å., \& Lie, I. (2016). Reindrifta i Finnmarks betydning for næringsutvikling og samfunnsutvikling. In E. Angel, S. Eikeland, \& P. Selle (Eds.). Nordområdene i endring - Urfolkspolitikk og utvikling. (p. 182-207). Oslo: Gyldendal Akademisk.

Sandel, M. (2012). What Money Can Not Buy: The Moral Limits Of Markeds. Farrar. New York: Straus and Giroux.

Schiefloe, P. M. (2019). Mennesker og samfunn. Bergen. Fagbokforlaget, 3 utg.

Shammas, V. L. (2019). Surplus populations and the state: A criminological view. Journal for Crime, Justice and Democracy. 8:1,131-146.

https://doi.org/10.5204/ijcjsd.v8i1.1032

Smith, A. (1759). Moral sentiments. Scholar Select.

Statistisk sentralbyrå (SSB). (2019). Fattigdomsproblemer, levekårsundersøkelse.

Retrieved 11. april 2019 from http://www.ssb.no/sosiale forhold og kriminalitet/statistikker/fattigdom.

St.prp.nr 1. (2006-2007). Handlingsplan mot fattigdom.

Slagstad, R. (2019). Spillet om Ullevål sykehus (et doldisbyråkratisk larestykke). Oslo: PAX Forlag A/S.

Solstad, A. (2011). Pengene og livet. Økonomisk rådgivning $i$ sosialt arbeid. Oslo:

Universitetsforlaget.

Svendsen, L. F. H. (2011). Arbeidets filosofi. Oslo: Universitetsforlaget.

SDG Progress report: https://unstats.un.org/sdgs/report/2017/SDG Progress

Report 2017, retrieved 20/12-1. 
Taylor, C. (1994). The politics of recognition. in A. Gutmann (ed):

Multiculturalism. Princeton University Press.

https://doi.org/10.1515/9781400821402-004

The Research Council of Norway: (Norges Forskningsrad) https://forskning. no/norges-forskningsrad-partner-sosiale-relasjoner/fattige-sliter-medskamfolelse/332556. Retrieved 26/7 2017.

Tranøy, B. S. (2014). Markedets makt over sinnene. Oslo: Aschehoug.

Valmyr, B.E. (2017). Educational Footprints and Psychosocial Factors in Multicultural Contexts in Arctic Norway A Cohort and Registry Data Study among Sami and Non-Sami Students, 2003-2012. PhD thesis. UiT The Arctic University of Norway.

Underlid, K. (2008). Fattigdommens lukt og smak- funn frå ein studie om korleis fattigdom vert opplevd. Tidsskrift for psykisk helsearbeid, 5(3):213-222.

Ween, G. B. (2017). Protection of Sámi intangible cultural heritage and intellectual property rights, and its relation to identity politics in a postcolonial Norway. In C. Antons \& W. Logan (ed.). Intellectual Property, Cultural Property and Intangible Heritage. (p. 157-174). Oxon, New York: Routledge. https://doi.org/10.4324/9781315714288-8

Ween, G. B., \& Lien, M.E. (2017). Indigenous land claims and multiple landscapes: postcolonial openings in Finnmark, Norway. In L. Head, Lesley; K .Saltzman, Setten \& M. Stenseke (Eds.). Nature, temporality and environmental management. Scandinavian and Australian perspectives on peoples and landscapes. (p. 133-149), Oxon, New York: Routledge. 